\title{
Linguistic techniques of creating humour of magic in T. Pratchett's novels
}

\author{
Y. Ukrayinska \\ Kyiv National Linguistic University, Kyiv, Ukraine \\ Corresponding author. E-mail: eugenie.ukr@gmail.com
}

Paper received 09.09.20; Accepted for publication 24.09.20.

\begin{abstract}
https://doi.org/10.31174/SEND-Ph2020-235VIII70-13
\end{abstract}
\begin{abstract}
Annotation. This paper addresses a set of linguistic techniques used to create the effect of humour of magic, the latter embracing magical characters, situations, and dialogues in Terry Pratchett's novels. The research focuses on those manifestation of humour that are grounded in ambiguity and incongruity related to semantic, situational, and conversational levels of literary texts under study. The paper aims to reveal various ways of transforming conventional magical elements into recognizable humorous ones. The analysis proves that linguistic techniques employed in the narrative (magical situations), descriptions (magical characters), and dialogues are mostly associated with the protagonists' usage of magic. The humour of magic in dialogues tends to be explicit, being caused by the character's unexpected reactions, whereas the humour generated by magical characters and/ or situations is mostly implicit, requiring for its comprehension the readers' cultural and social background knowledge.
\end{abstract}

Keywords: humour, magical character, magical situation, magical dialogue, humourous effect, incongruity, ambiguity.

Humour was not associated with fantasy literature until the late 1960-s [3, p.42]. However, later this genre proved to be of significant interest for scholars who address the phenomenon of humour from its textual perspective. Humour appears to be one of ways of creating a new reality where verbal means are of major importance, because they bring together the author's individual worldview and cultural, linguistic as well as social conventions [2, p.172]. Such an interface emerges due to associative structures the readers need to interpret the comic in the context of ludic verbal structures [1, p.7], which provide common analogies based on the readers' shared and personal experience. Given the above, this paper concentrates on the analysis of Terry Pratchett's book series "Discworld" as the main source of material for research.

Terry Pratchett's Discworld is an illustrative example of alternate fictional fantasy world with magic as an essential part. However, it is not magic in its classical format but something stronger, mainly due to its non-conventionality. Describing magic as a phenomenon, Pratchett claims that the magical core of his imaginary universe is even more powerful than magic per se. He states: "What runs Discworld is deeper than mere magic and more powerful than pallid science. It is narrative imperative, the power of story. " [4, p.10]. Given that magic in literary text as an object of our research being the crucial element of Pratchett's novels undergoes transformations into the laugh-provoking category, the interaction of magic and humour is presented here as the subject-matter of this study. For that reason, the main task of the paper is to reveal how the humourous effect of magic is achieved at different textual levels in Pratchett's book series. The novelty and topicality of the research proceed from establishing the linguistic mechanisms by which the categories of magic and humour become textually intergrated. We distinguish three text levels at which such integration emerges: (i) semantic, where magical characters transform into comic ones, (ii) narrative, where magic triggers humorous situations in the narrative, and (iii) conversational, where dialogues between characters disclose the comic nature of magic.

Semantic manifestations of humorous magic in Pratchett's novels with its subclasses and subcategories are the most difficult for analysis. They deal with magical characters that fall into two main subcategories - situational and stable. Situational characters are generally confines to one novel, whereas stable ones can be found in the whole series of Pratchett's books. These two subcategories fall into five main subclasses: Gods of Discworld (stable), Wizards and Sorcerers (stable), Witches (both stable and situational), Anthropomorphic Personifications (both stable and situational), Magical Creatures (both stable and situational). However, the humorous effect of both situational and stable magical characters is based on the same linguistic techniques, comprising the description of characters and the reliance on the vertical context to resolve incongruity and ambiguity of Discworld's magical reality. Such humourgenous incongruity and ambiguity may be marked by puns, the discrepancy of literal and figurative meanings, connotations, contrasts and metaphors as the main linguistic techniques used to create a magic-based humour.

Puns that employ the names of various magical creatures, e.g. gods, wizards, or witches, especially speaking names, play a most essential role in creating humour in Pratchett's novels. Some gods have names based on wordplays, like: Errata - the goddess of misunderstanding (a nonce-word from spelling error), Vometia - the goddess of nausea (from the verb "to vomit"), Pathina - the goddess of wisdom. Her name is especially interesting semantically, because it combines two mechanisms - blending and reinterpretation. On the one hand, this name is a blend of two elements - the name of the Greek goddess Athena, whose symbolic animal was an owl, a symbol of wisdom, and the mention of penguin that is shown as a symbol of naivety: "What was that bird that walked in when the Goddess" - he tasted the unfamiliar word - "of Wisdom was mentioned?" "Bit of a problem there," said the barman. "Bit of an embarrassment." "Sorry?" "It was," said the barman, "a penguin." "Is it a wise sort of bird, then?" "No. Not a lot," said the barman. "Not known for its wisdom. Second most confused bird in the world. Can only fly underwater, they say." "Then why-" "We don't like to talk about it," said the barman. "It upsets people. Bloody sculptor," he added, under his breath." (SG: 264). Here, through the contrast of "wise - confused", "wisdom - embarrassment" the image of the goddess of wisdom is humorously understated. On 
the other hand, this name evokes associations with the word "patina" used to describe the skin of different metal surfaces as a result of metal oxidation, so this word is widely known among antique dealers to identify the specificity of the product surface. As a result, the name of the goddess of wisdom identifies her as a goddess possessing a superficial wisdom only.

Similar semantic transformations occur in naming wizards and witches. Wizards' proper names, e.g. Ridcully, Poons, Rincewind, are very thought-provoking due to verbal games. Thus, the name of the Arc chancellor of Unseen university, Ridcully, is a pun based on the word "ridiculous", which clearly characterizes the level of his intelligence: "Mustrum Ridcully was notorious for not trying to understand things if there was anyone around to do it for him." (LC: 12). Ironically using the negatively connoted adjective "notorious" in combination with this pun to describing Ridcully's duties (not trying to understand things), Pratchett creates a humorous image of the wizard. This character's name is accompanied by the name of the series's protagonist, wizard Rincewind. His name is a blend of two words - the verb "to run" (the Old English "rinnan") and the noun "wind". The meaning of this blend becomes clear, when we come across this person's motto in the novel "Eric":| "Pre-eminent amongst Rincewind's talents was his skill in running away, which over the years he had elevated to the status of a genuinely pure science; it didn't matter if you were fleeing from or to, so long as you were fleeing. It was flight alone that counted. I run; therefore, I am; more correctly, I run, therefore with any luck I'll still be. " (E: 58). Judging by this excerpt, the main talent of this magical person is not to create magic but run fast from troubles, which is marked by phrase "to fleet from and to" as well as the allusion to Descartes' famous I can think, therefore I am (Cogito ergo sum).

While analyzing the names of witches, we can assume that Pratchett's purport, when naming these magical creatures, was to contrast the form and the content. One of the most powerful witches' name, Nanny Ogg, has an occult background. An ogre is a legendary monster usually depicted as a large, hideous, man-like being that eats people, especially infants and children [5]. Ascribing such a name to a witch, the author predictably bears in mind the readers' expectations as to her appearance and character. However, the witch's portrait does not meet these expectations: "The door was opened by a small, fat, rosy-cheeked woman whose little currant eyes said, yep, that's my gnome all right, and be thankful he's only widdling in the pond. "Mrs Ogg? The midwife?" There was a pause before Mrs Ogg said, "The very same." (TTOT: 368). Here, the chain of descriptive adjectives "small", "fat", "rosy-cheeked" outlines an image of the witch, whose profession we are unable to guess because of the discrepancy between her name and appearance, i.e. the name's form and content, which creates ambiguity due to its contrast with the conventional, classical witch's image, thus causing a humorous effect.

While creating humour semantically, Pratchett does not only use self-speaking names, but also plays on contrasts between conventional magical personae and their roles in doing magic in his novels. Thus, the readers' image of a conventional wizard correlates with the one described by J.R.R. Tolkien in his "Lord of the Rings", cf.: "Gandalf was shorter in stature than the other two; but his long white hair, his sweeping silver beard, and his broad shoulders, made him look like some wise king of ancient legend. In his aged face under great snowy brows his eyes were set like coals that could suddenly burst into fire." (LoR 1:35). "He had a tall pointed blue hat» (H: 24); "You cannot pass,' he said. The orcs stood still, and a dead silence fell. 'I am a servant of the Secret Fire, wielder of the flame of Anor." (LoR1: 344). So, for many readers a wizard is an old man, wearing a hat and using magic. In one of the first novels of Discworld series, such a wizard is presented in the way common to conventional fantasy representatives of this occupation: "he was a wizard, partly because of the long cloak and careen staff... A wizard who knows he's going to die can sort of pass on his sort of wizardness to a sort of successor, "So you're going to sort of die?" (ER: 12). The wizard here does have a magical artifact (careen staff), possesses magic powers (sort of wizardness), being an aged man into the bargain (you're going to sort of die). However, in the later novel "Light Fantastic" we come across the explanation of magical competence of the Discworld wizards' magical competence: "I thought wizards knew all about trees and wild food and things,' said Twoflower reproachfully. It was very seldom that anything in his voice suggested that he thought of Rincewind as anything other than a magnificent enchanter, and the wizard was stung into action. 'I do, I do,' he snapped. 'Well, what kind of tree is this?' said the tourist. Rincewind looked up. 'Beech, ' he said firmly. 'Actually_' began the tree, and shut up quickly. It had caught Rincewind's look." (LF: 38). Here we see a wizard, who knows nothing about nature, allowing magical trees to correct him ('Actually_-' began the tree, and shut up quickly), which creates the effect of abruptness and, with much probability, makes the reader laugh.

The witches' characters in Pratchett's novels is also far from being conventional. The word "witch" originates from the Old-English "wicce", which meant a woman-wizard and sorcerer. In "The Laws of Aelfred", a witch was a woman who had strong bounds with supernatural powers and could resurrect after death: "fcemnan pe gewuniad onfon gealdorcrceftigan \& scinlcecan \& wiccan, ne loet pu ða libban" (LA: 890). In this example the word "gewuniað" means the ability of a witch to ressurect and the word "scinlcecan" a ghost, implying that witches can communicate with supernatural creatures. The excerpt below taken from Pratchett's novel "Equal Rites" states that Discworld witches have much in common with a classical witch: "The midwife's name was Granny Weatherwax. She was a witch. That was quite acceptable in the Ramtops, and no one had a bad word to say about witches. At least, not if he wanted to wake up in the morning the same shape as he went to bed." (ER: 20). Thus, a witch is a person who has magical powers to transform people into different shapes (not if he wanted to wake up in the morning the same shape as he went to bed). Nevertheless, what makes this magical character humorous is the incongruity between the idea of magic and its form of realization. In the same novel the head witch, Mother Weatherwax, explains to her student what magic really is: "Most magic isn't," she said. "It's just knowing the right herbs, and learning to watch the weather, and finding out the ways of animals. And the ways of people, too" (ER: 80). According to her, the Discworld 
magic is nothing but a highly developed sense of watchfulness (knowing the right herbs, and learning to watch the weather, and finding out the ways of animals), which gives a witch the advantage and the power to control people. This absence of magic in a magical character, which is definitely nonsense, creates another between expectations and reality, ruining the borders between them and thus creating a humorous effect.

At the narrative textual level the humorous effect is achieved through the description of the situations where magical symbols are used, magical phenomena are involved, magical subworlds are visited by the protagonists. Pratchett's Discworld is a home for several magical subworlds, such as: Dungeon Dimensions (a prison for Creatures and Things), L-Space (Library), Dark Desert (Purgatory), Midgard (Planet Neighbour). Dungeon Dimensions is a magical place with a huge accumulation of magic, so Creature and Things that stay there gather together, hoping someone will pronounce the sacred figure 8 , which is associated with them, and they will be free to kill him/her. In "The Colour of Magic", the main characters, a tourist Twoflower and a wizard Rincewind, accidentally mention this figure and the Creatures appear: "Strange," it said. "Why can't he say eight?" Eight, hate, ate said the echoes. There was the faintest of grinding noises, deep under the earth.... A charge of magic bigger than he had ever seen was building up; when he moved, in painful slow motion, his limbs left trails of golden sparks that traced their shape in the air. Behind him there was a rumble as the great octagonal slab rose into the air, hung for a moment on one edge, and crashed down on the floor. Something thin and black snaked out of the pit and wrapped itself around his ankle." (CM: 95) In this situation the figure 8, repeated several times, and adjective "octagonal" act as allusions to the sacred number 7, usually used in fairy-tales (seven dwarfs, seven kings, seven petals). The repetition of this number in combination with rhyming of past form of the verb "to eat" - "ate" and the verb "to hate" creates the impression of fear caused by these magical creatures' power. Nevertheless, the development of this situation makes us come to another conclusion: "They're about ripe now, can't hold them any longer. Everyone smile, please." There was a flash of light so white and so bright it didn't seem like light at all. Bel-Shamharoth screamed, a sound that started in the far ultrasonic and finished somewhere in Rincewind's bowels. The tentacles went momentarily as stiff as rods, hurling their various cargoes around the room, before bunching up protectively in front of the abused Eye. The whole mass dropped into the pit and a moment later the big slab was snatched up by several dozen tentacles and slammed into place, leaving a number of thrashing limbs trapped around the edge." (CM: 103) The situation becomes humorous due to exaggerating the power of non-magical technology, which leads to incongruity between the readers' expectations and the reality of Discworld, where the usage of a modern device (a camera to make a photo) helps to take the upper hand over the magical creatures (here was a flash of light so white and so bright it didn't seem like light at all), who therefore loses all their powers and becomes weak.

The figure 8, as one can see earlier, is very important for Discworld's magic. It does not only calls monsters out of dungeons, but also is an integral part of every wizard's life.
There are eight main spells in Octavo Grimoire (the major book of Spells), and there is the colour "octarine", integrating eight rainbow colours and associated with the colour of magic. Defining a colour through colours is another example of creating a humorous effect based on incongruity between expectations and reality: "It was octarine, the colour of magic. It was alive and glowing and vibrant and it was the undisputed pigment of the imagination, because wherever it appeared it was a sign that mere matter was a servant of the powers of the magical mind. It was enchantment itself. But Rincewind always thought it looked a sort of greenish-purple." (CM: 342). Here, Octarine is shown as a powerful creature, not just a colour, with the help of a metaphor - a servant of the powers of the magical mind, and personification - alive and glowing and vibrant, but the magical effect of its power is completely ruined, becoming absurd and therefore humorous due to disclosing its real featureless colour - greenish-purple, the colour that has little to do with true nobility and enchantment.

Narrative situations that involve magical rituals have their own humorous specificity due to verbal games that ruin the borders between magic and reality. In the excerpt from the novel "Mort" the protagonist, not really a wizard, who is trying to perform a magical ritual: "He opened it with difficulty and unfolded a dusty grey robe that scattered mothballs and tarnished sequins across the floor. There was a lot of muffled cursing and the occasional clink of china and finally Albert emerged holding a staff taller than he was. It was thicker than any normal staff, mainly because of the carvings that covered it from top to bottom. ... Then he said, 'Hat. No hat. Got to have a hat for the wizarding. Damn. 'He stamped out of the room and returned after a busy fifteen minutes which included a circular hole cut out of the carpet in Mort's bedroom, the silver paper taken out from behind the mirror in Ysabell's room, a needle and thread from the box under the sink in the kitchen and a few loose sequins scraped up from the bottom of the robe chest. The end result was not as good as he would have liked and tended to slip rakishly over one eye, but it was black and had stars and moons on it and proclaimed its owner to be, without any doubt, a wizard, although possibly a desperate one." (M: 388). The usage of enumeration (robe, staff, hat) in combination with the negatively charged adjectives (desperate, indistinct) creates a humorous image of the wizard, who does not really need magic for his rituals, only suitable clothes, which makes no sense, making the readers laugh.

The conversational textual level, the last to be analyzed in this paper, comprises personages' dialogues, which deal with both magic as a phenomenon and duties and deeds of various magical creatures or personified artifices. The humorous effect of magic in dialogues is created due a violation of reason-consequence connection which causes incongruity between magic and its understanding by the characters. It can be illustrated by the dialogue between witches, who discuss a Fairy Godmother's duties: "She waved the wand in a vague way and tried to put pumpkins out of her mind. She felt the air move. She heard Nanny gasp. She said, "Has anything happened?" After a while Nanny Ogg said, "Yeah. Sort of. I hope they're hungry, that's all." And Granny Weathenvax said, "That's fairy godmothering, is it?" Magrat opened her eyes. There was still a heap, but it wasn't rock any more. "There's a, wait 
for it, there's a bit of a squash in here, " said Nanny. Magrat opened her eyes wider. "Still pumpkins?" (WA: 96). In this excerpt, humour is created when the witches find themselves inapt to understand what they are charged with, which is marked by the question-answer series (Has anything happened? That's fairy godmothering, is it?) in combination with the allusion to "Cinderella" (Still pumpkins?), which ruins the atmosphere of miracle, because whatever the witches are trying to create transforms into a pumpkin. The effect of magical ritual is broken and becomes understated, as the success of the ritual belongs only to those who have a magic stick and can transform things into pumpkins.

The novel "Wyrd sisters" contains the dialogue between witches, who discuss what is really necessary for conducting a magical ritual. The reader would rather expect that in order to conduct a ritual, a witch should probably have some spiritual power. However, the exchange of remarks between the characters ruins these expectations: "Granny Weatherwax paused with a second scone halfway to her mouth. 'Something comes, 'she said. 'Can you tell by the pricking of your thumbs?' said Magrat earnestly. Magrat had learned a lot about witchcraft from books. 'The pricking of my ears, ' said Granny." (WS: 24). The verbal game with questions and answers, based on direct and figurative meanings of the phrases "to prick one's thumbs/ears" and "to prick up one's ears" undervalues the importance of magical ritual, thus creating a humorous effect.

Having analyzed the interface of humour and magic at three different textual levels (semantic, narrative, and conversational), we come to the conclusion that the main linguistic techniques that help create a humorous effect in Pratchett's novels are exaggeration of magic powers, the usage of contrast, abruptness, nonsense, and absurdities while describing magical creatures, their duties or rituals, verbal games, including puns based on magical character's names. All these techniques, together with addressing the novels' vertical contexts, lead to ambiguity or incongruity between the readers' expectations and magical reality of Discworld as a source of humour grounded in the reinterpretation of magic.

\section{ЛИТЕРАТУРА}

1. Александрук І.В. Вербалізація можливих світів у жанрі фентезі (на матеріалі творів сучасних англійських та американських авторів): Автореф. дис. канд. філол. наук: 10.02.04 "Германські мови". - Харків, 2011. - 18 с.

2. Дембовська Л.М. Оказіональні композити в ідеодискурсі Джерома К. Джерома. // Вісник Житомирського державного університету ім.. І. Франка. - Житомир. - 2009. - № 4. - C. $172-175$

3. Свмененко О.В. Місце гумористичного фентезі в сучасній читацькій культурі // Від смішного до великого: феномен комічного в літературі та культурі: зб. наук. матеріалів конференції (Бердянськ, 28-29 вересня 2017 р.) / [гол. ред. О. П. Новик]. - Бердянськ, 2017. - С. 42.

4. Pratchett Terry, Stewart Ian and Cohen Jack. The Science of Discworld I. - Clays: Ebury Press. - 2013. - 336 p.

5. Warner Marina. Why do Ogres Eat Babies?. - режим доступу http://www.doi:10.1007/978-1-349-13816-6_18

6. ER: Pratchett T. Equal Rites. - London: Corgi Books, 1987. $283 \mathrm{p}$.

7. E: Pratchett T. Eric. - London: Gollancz, 1990. - 118 p.
8. GG: Pratchett T. Guards! Guards! - New York: Harper Collins, 2008. $-355 \mathrm{p}$.

9. COM: Pratchett T. The Colour of Magic. - London: Corgi Books, 1985. - $285 \mathrm{p}$.

10. LC: Pratchett T. The Last Continent. - London: Corgi Books, 1999. $-412 \mathrm{p}$.

11. LF: Pratchett T. The Light Fantastic. - London: Corgi Books, 1986. -285 p.

12. M: Pratchett T. Mort. - London: Corgi Books, 1988. - 272 p.

13. SG: Pratchett T. Small Gods. - New York: Harper Collins, 1992. $-384 \mathrm{p}$.

14. TTOT: Pratchett T. The Thief of Time. - London: HarperTorch, 2002. -

15. WA: Pratchett T. Witches Abroad. - London: Corgi Books, 1993. $-275 \mathrm{p}$.

16. WS: Pratchett T. Wyrd Sisters. - New York: Harper Collins, 2008. $-265 \mathrm{p}$.

17. LotR1: Tolkien J.R.R. The Lord of the Rings. Part 1: The Fellowship of the Ring. - London: Unwin Hyman, 1974. - 544 p.

\section{REFERENCES TRANSLATED AND TRANSLITERATED}

1. Aleksandruk I.V. Verbalizatsiya mozhlyvyh svitiv u zhanri fantasy (na materiali tvoriv suchasnyh angliys'kyh ta amerykans'kyh avtoriv): Avtoref. dys.kand.filol.nauk: 10.02.04 "Hermans'ki movy". - Kharkiv, 2011. - 18 p.

2. Dembovs'ka L.M. Okasinal'ni komposity v ideodyskursi Jerome K. Jerome. // Visnyk Zhytomyrs'koho derzhavnoho universytetu im. I. Franka. - Zhytomyr. - 2009. - №4. - P. 172175.

3. Yevmenenko O.V. Mistse humorystychnoho fantasy v suchasniy chytats'kiy kul'turi //Vid smishnoho to velykoho: Fenomen komichnoho v literaturi ta kul'turi: zb. nack.materialiv konferentsii (Berdyans'k, 28-29 veresnya 2017 r.) / [hol. red. O.P. Novyk]. - Berdyans'k. - 2017. - S. 42

4. Pratchett Terry, Stewart Ian and Cohen Jack. The Science of Discworld I. - Clays Ebury Press. - 2013. - p. 10

5. Warner M. Why do Ogres Eat Babies?. - Режим доступу http://www. doi 10.1007/978-1-349-13816-6_18

6. Pratchett T. Equal Rites. - London: Corgi Books, 1987. - 283 p.

7. E: Pratchett T. Eric. - London: Gollancz, 1990. - 118 p.

8. GG: Pratchett T. Guards! Guards! - New York: Harper Collins, 2008. $-355 \mathrm{p}$.

9. COM: Pratchett T. The Colour of Magic. - London: Corgi Books, 1985. $-285 \mathrm{p}$.

10. LC: Pratchett T. The Last Continent. - London: Corgi Books, 1999. $-412 \mathrm{p}$.

11. LF: Pratchett T. The Light Fantastic. - London: Corgi Books, 1986. -285 p.

12. M: Pratchett T. Mort. - London: Corgi Books, 1988. - 272 p.

13. SG: Pratchett T. Small Gods. - New York: Harper Collins, 1992. $-384 \mathrm{p}$.

14. TTOT: Pratchett T. The Thief of Time. - London: HarperTorch, 2002.-

15. WA: Pratchett T. Witches Abroad. - London: Corgi Books, 1993. $-275 \mathrm{p}$.

16. WS: Pratchett T. Wyrd Sisters. - New York: Harper Collins, 2008. $-265 \mathrm{p}$.

17. LotR1: Tolkien J.R.R. The Lord of the Rings. Part 1: The Fellowship of the Ring. - London: Unwin Hyman, 1974. - 544 p. 